\section{The landscape of public service innovation in Indonesia}

\section{Public service innovation in Indonesia}

\section{A comprehensive analysis of its characteristic and trend}

\author{
Arif Budy Pratama \\ Department of Public Administration, Universitas Tidar, KotaMagelang, Indonesia
}

\begin{abstract}
Purpose - The purpose of this paper is to provide a comprehensive analysis of Indonesia's public service innovation drawn from the top 99 nominees of the national competition for public service innovation from 2014 to 2016.

Design/methodology/approach - To answer the research question, this study applied archival research as a research strategy. A documentation method was conducted to collect the data. Using content analysis aided by NVivo 11 this study analyzes the following themes: implementing agencies, innovation types, innovation goals, innovation outcomes, policy sector in which innovation implemented and geographical perspective.

Findings - The public service innovation in Indonesia from 2014 to 2016 were dominated by local government and process innovation in which designates to the amalgamation of technological and administrative dimensions of innovation. The most occurrence outcomes were aimed to tackling societal problems in the health and education sector. Whilst in the geographical perspective, big portion of innovation were taking place in Java Island.

Research limitations/implications - The result of this study is mainly based on secondary data drawing from public service innovation competition held by the Indonesian Ministry of Administrative Reform. Consequently, the result is limited to provide a mapping feature and trends of innovation. Future research may use more extensive samples (not only sourced from the nominees but also all submitted initiatives) to obtain more representation of public service innovation in Indonesia.

Practical implications - Given the fact that lack of collaboration between public and private actors, the government needs to consider on designing strategies and policy direction to foster collaboration in public service innovation.

Originality/value - This research offers a comprehensive analysis on Indonesian public service innovation. Methodologically, the research introduces archival research as one of the alternative research strategies on public sector innovation scholarships.
\end{abstract}

Keywords Content analysis, Archival research, Innovation types, Innovator,

Public service innovation

Paper type Research paper

\section{Introduction}

Recently, innovation in the public sector is gaining more attention by both academics and practitioners. Public sector innovation has become a political and administrative agenda in

(C) Arif Budy Pratama. Published in Innovation \& Management Review. Published by Emerald Publishing Limited. This article is published under the Creative Commons Attribution (CC BY 4.0) licence. Anyone may reproduce, distribute, translate and create derivative works of this article (for both commercial and non-commercial purposes), subject to full attribution to the original publication and authors. The full terms of this licence may be seen at http://creativecommons.org/licences/by/4.0/legalcode

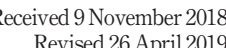
Accepted 8 October 2019 
INMR

17,1

many advanced western democracies (Borins, 2008) and soon diffuses to developing countries. By implementing innovation, public organizations may improve public service quality (Damanpour \& Schneider, 2009) and enhance service performance (Walker, Jeanes \& Rowlands, 2002). To achieve effectiveness and efficiency, governments mostly depend on successful innovation using resources and technologies (Mulgan \& Albury, 2003).

The importance and virtues of public sector innovation have pushed national governments around the world to implement innovation policy for better public services. The Government of Indonesia also commits to support public service innovation through national regulatory framework. The Government Regulation Number 38 Year 2017 on local innovation regulates how local governments conduct local innovation. The scope of the policy includes innovation of governance arrangement and public service delivery.

Besides the directive intervention through regulation, awards and competition for public organizations are one of alternative ways to spur innovation in the public sector. Numbers of competitive award schemes on public services have been growing significantly as a means to both celebrate high performance and spread good practices (Hartley \& Downe, 2007).

Since 2003, the United Nations through the Department of Economic and Social Affairs has launched The United Nations Public Service Awards (UNPSA) to appreciate successful innovations implemented by governments and public organizations across five continents. This initiative is also followed by many countries including Indonesian Government. The Ministry of Administrative Reform of the Republic of Indonesia has organized the competition for public service innovation since 2014. It is aimed to select innovators as country representatives in the UNPSA.

The Indonesia National Competition for Public Service Innovation has yielded enthusiasm from various public organizations. It was indicated by the growing number of submitters from year to year. It started in 2014 with 515 registered-competitors, it increased by 130 per cent in 2015, which recorded 1,189 submitters. This recurred in 2016 with 2,476 registered submitters (KemenpanRB, 2017). All submissions were evaluated through online desk-based assessment by independent examiners resulting top 99 innovators. The final judgment was top 9 in 2014, top 25 in 2015 and top 35 in 2016 competition year. This demonstrates more and more government agencies, as well as public organizations in Indonesia are willing to innovate in providing public services.

However, limited effort has been done to investigate the public service innovation initiatives comprehensively. Thus, little elucidation has been known about public service innovation in Indonesia, especially those which were recognized and assessed by the Ministry of Administrative Reform. In the academic realm, research on public sector innovation as one of reform mechanism is not something new and has been widely studied in public administration scholarships. Surprisingly, most of the publications themed public innovation were relatively new since they published between 2009-2014 and highly focused on the American-Anglo-Saxon perspective (De Vries, Bekkers \& Tummers, 2016). In addition, the study in the regional and international perspective tends to emphasize the metric, index and measurement instrument for public sector innovation and they mostly take place in the western context (Bloch \& Bugge, 2013; Walker, Jeanes \& Rowlands, 2002).

While, in the Indonesian context, research on public innovation mostly emphasizes on technological innovation and case studies approach (Anggadwita \& Dhewanto, 2013; Fahlevi, 2014; Jati, 2011; Kusumasari, Setianto \& Pang, 2018; Lembaga Administrasi Negara, 2014; Santoso, 2015; Sutanto, 2017). These published studies have not been able to capture the big picture of Indonesia's public service innovation. In other words, none of the above studies offers a comprehensive analysis of public service innovation implemented by public organizations in Indonesia. 
Given the research gap, especially the context in which public service innovations have occurred, there is an encouragement to study public service innovation in the non-western administration system. A comprehensive analysis in one specific country across time will be beneficial, as it offers an alternative perspective on this issue.

The purpose of this paper is to conduct a comprehensive analysis of Indonesia's public service innovation characteristic drawn from the Indonesian Public Service Innovation Competition 2014-2016. Pragmatically, this study aims to capture the landscape of Indonesia's public service innovation during these periods. Understanding the landscape of public service innovation may enhance our understanding on how innovation had been implemented by various public organizations in Indonesia. Thus, government can use the result of this study as a baseline fact in designing public service innovation policy. Theoretically, this study will provide a comprehensive description of public service innovation in Indonesia's context as one of the examples of specific non-western public administration system.

The remaining parts of this paper will structure as follows. Firstly, the author will synthesize the major themes of innovation in the public sector especially public service innovation from the review of literature. Secondly, the author formulates a framework to analyze the landscape of public service innovation in Indonesia. Finally, the result then will be discussed before drawing a conclusion and identify future research trajectories.

\section{Innovation in the public sector}

A historical sketch and snapshot of literature

To understand public service innovation, it is necessary to trace the notion of innovation to get a comprehensive idea of the terminology and its usage within public sector context. The word "innovation" was coined by Schumpeter in late 1920 (Hansen \& Wakonen, 1997; Sweezy, 1943; Ziemnowicz, 2013) to designate the commercial applications of new technology, new material, and new methods in the advancement of economic development and industrialization. Thus, compared to public sector, innovation studies in the area of business and private sector is more established field of study (Fragerberg, Mowery \& Nelson, 2005). What makes different between public and private innovation is the driving force in its implementation. The former emphasizes on public goods and public values, which means government agencies push innovation programs to achieve widespread improvements in governance and service performance, including efficiencies and the effort to increase public value. While the latter is obsessed by competitive advantage and profitoriented motives (Urbancova, 2013).

In public administration scholarships, the study of innovation firstly emerged in 1960s. The article titled Innovation in Bureaucratic Institutions was published in the Public Administration Review (Diamant, 1967). Two years later, an article titled Administrative Reform by Caiden (1969) was published arguing that innovation in the public sector is part of administrative reforms. These publications were regarded as the starting point of innovation studies in the public sector. The development of public sector innovation research has promised a bright future (Walker, 2013). Recently, an interest to uncover the unknown properties of innovation in the public sector has been growing rapidly. A comprehensive study on public sector innovation conducted by De Vries et al. (2016) offers an extensive review of literatures on public sector innovation. Their systematic review of literature based on empirical research of English written publication in international peerreviewed journal spanning from January 1990 to March 2014 provide a clearer picture on how innovation evolves in the public sector. As a systematic review, which was conducted
Public service innovation in Indonesia 
INMR

17,1

transparently from highly cited and reputable academic journals, their work offers a robust analysis and represents the body of literature in the public sector innovation research.

Based on their study, some key results have been identified. Firstly, most of the public sector innovation studies are qualitative in which case study approach was used as a research design, while, quantitative and mixed-methods studies are smaller in numbers. The biggest proportion of the available literature comes from the western context. Secondly, the largest portions of innovation studies were conducted on the local government level, followed by central government and other public and non-profit organizations. Thirdly, many innovation studies put their central attention on the multiple policy fields followed by healthcare sector, yet few studies scrutinize welfare or education subsectors. Finally, organizational antecedents play the largest role in enabling all innovation types while governance innovations are frequently connected to environmental antecedents, including the resources of private partners. These key results have informed the states of public sector innovation research and the call for more comprehensive analysis especially in the developing world.

\section{Defining innovation in the public sector}

Innovation is a complex concept and has been defined in many different ways. The definition is highly leaned on its context, disciplinary background and its research streams. The cross-disciplinary nature of innovation studies and its various methodologies have also contributed to its dispersed meaning. Simply put, innovation is regarded as "doing things differently" (Hansen \& Wakonen, 1997). In the public sector, specifically, Mulgan and Albury (2003) define successful public innovation as the creation and implementation of new processes, products, services and methods of delivery in providing public services. It then results in significant improvements in outcomes, efficiency and effectiveness or public service quality. This definition underscores the nature of public domain and emphasizes on administrative values.

Other scholars highlight the importance of creativity, which means creating new ways of doing something. This is in line with the root of economic and management science that suggests innovation as a novelty in action. Scholars with novelty-perspective believe the echo of innovation is accentuated in a novelty concept. Bhatti, Olsen and Pedersen (2011) underscore that novelty as the core characteristic of innovation. The outcomes are reflected in the new products, methods of production, markets, sources of supply and organizational structure. This perspective can be clustered into a novelty-based definition.

Another cluster deals with the adoption process. This perspective perceives innovation as the act of adopting. It is not only for invention or something that emerges for the first time but also the use of existing idea in the new settings and contexts. Rogers (2003) defines innovation as "an idea, practice or object that is perceived as new by an individual or another unit of adoption." Complementing that idea, Rogers, Medina, Rivera and Wiley (2005) emphasize on the notion of innovation as a "diffusion." This argument is in same boat with Hartley (2005), who argues that innovations may include reinvention or adoption to another context, location or time frame. The innovation as adoption process is highly supported by the policy transfer and policy diffusion studies (Dolowitz \& Marsh, 1996, 2000; Evans \& Davies, 1999; Mccann \& Ward, 2013; Stone, 2001).

For this study, public sector innovation is composed by both streams of conceptions. The public service innovation is defined as the implementation of a new idea or modification of idea that has been used in another context to improve public service performance. Similarly, Lembaga Administrasi Negara [Indonesian Institutes of Public Administration (2014)] defines public sector innovation to designate the public sector in Indonesia as a process by 
which public institutions implement policies for public good characterized by its originality and outcome-based. This also corroborates to the Indonesian Minister of Administrative Reform Regulation Number 30/2014, which states innovation as a breakthrough and creative process and it is not always something new. The public service innovation can also be a modification of an existing innovation to improve public service delivery either directly or indirectly.

\section{Innovators}

One of the most important dimensions in studying innovation is to answer who implements the innovation process? Or who are the innovators? It is very crucial, as innovators are the doers and they are allegedly the core subject matters of innovation itself. In the era of governance, public service provision can be provided by many providers. Nowadays, government is not the only actors who deliver public services to its citizens. The network governance approach has been influenced the ways in which public services being provided to meet citizen expectations (Ansell, Torfing \& Keast, 2017; Klijn \& Koppenjan, 2012; Ulibarri \& Scott, 2017).

In line with that phenomena, Sørensen and Torfing (2012) and Bommert (2010) see innovation within the public sector on actor-based perspective that demands collaborative action among government agency, as well as private sector and community organizations. This addresses the collaborative features in the management of public sector. Osborne, Radnor \& Strokosch (2016) come with an emphasis on co-production and the co-creation in public services. The above arguments paradigmatically integrate with the importance of various stakeholders shaping networked governance in the public innovation process (Hartley, 2005). Consequently, innovation in the public sector is not only done by government agencies alone but also the catalysts, which may come from other sectors and collaboration among policy actors are needed to accelerate the innovation. Thus, the collaboration features of innovation matter in the study of innovation in public sector.

\section{Innovation types, goals and outcomes}

Innovation in the public sector can be manifested in many different faces (Rogers, 2003). Scholars have classified these variations based on their research streams. Osborne (1998) modified innovation type from an industrial setting introduced by Abernathy, Clark and Kantrow (1983). His typology is built from two dimensions include service of the agency and the needs of clients. The first type is developmental when innovation happens in the existing service and needs of clients. The second type is called expansionary when innovation happens in the existing service operating in the new needs of clients. The third type called evolutionary when the innovation happens in existing needs of clients with new kinds of services. Finally, innovation is total when it occurs in both new services and new needs of clients. This typology is relatively abstract due to its general context and the dynamic of citizen as client.

In the empirical facet, one of the most prominent cases is Innovations in American Government Awards held by Ford Foundation and the Harvard Kennedy School of Government. The implementation of innovation in the public sector based on local officials' perspective in the USA can be categorized in many types include holistic use of volunteers, technology, new management philosophy, process improvement, attitude change, empowerment groundwork for others, prevention, spillover benefits, uses incentives, pilot program and use of private sector. From that awards, Borins (1998) characterizes innovation as a new program, better marketing, partnership, organizational change, technological

Public service innovation in Indonesia 
INMR

17,1

application, privatization/competition and empowerment of clients. From time to time the types of innovation had been developed in many ways.

Lembaga Administrasi Negara (2014) offers a classification of public sector innovation into eight types. They are process innovation, methods innovation, product innovation, conceptual innovation, technological innovation, organizational structure innovation, relationship innovation and human resources development innovation. This classification was mainly used as examples of public service innovation, which emphasizes best practices.

A more comprehensive assessment drawing from a systematic review of literature conducted by De Vries et al. (2016) has classified public sector innovation into four big classifications. The first type is process innovation that focuses on the quality and efficiency of internal and external processes. One of the most representative literature can be referenced to Walker (2013), who examined a review of internal and external process of innovation within public sector. This type can be divided into two categories named administrative and technical innovation. The administrative innovation is focused on administrative tools in which innovation occurred such as organizational forms, introduction of new management methods and techniques. The example can be seen in the creation of new agency, reform of new standard operating procedures, etc. While, the technical innovation is better understand as the use of technologies in the innovation process. One of the most visible example is the implementation of electronic governance and the like.

The second type is product or service innovation, which focuses on the introduction of a new product or public service deliveries (Damanpour \& Schneider, 2009). The product innovation is found in the creation of aging society benefits or waste management facility. The third type is accentuated on the development of new forms and processes to address specific societal problems. This type of innovation is called governance innovation. An article by Moore and Hartley (2008) has been fronted to this type of innovation. The last type of innovation, according to the systematic literature review, is conceptual innovation, which introduces new concepts, frames of reference or new paradigms that help to reframe the nature of specific problems, as well as their possible solutions (De Vries et al., 2016). Given the robust foundation of systematic review, this classification may be considered a robust analytical framework to assess innovation types in the public sector.

\section{Goals and outcomes}

The endorsement of innovation in the public sector is aimed to address various societal needs and tackle public problems. Thus, the innovation practiced by public organizations should have a goal statement, which guides implementers during the innovation process. Aside of goals statement in the beginning, the outcomes of innovation should be assessed in the end of innovation cycle. In this logic, the goals statement in the beginning and the innovation impact as the outcome of programs are very important in evaluating public sector innovation. Drawing from research on public sector innovation for two decades, De Vries et al. (2016) have identified that at least six goals and outcomes are expected. The innovation in the public sector is aimed to increase effectiveness, efficiency, tackling societal problems, improve citizens' satisfaction, involve citizenry and involving private partner to contributing in public services.

\section{Policy sector and geographical aspect}

Another important point in understanding public sector innovation is to consider the area of policy in which innovations occur and where innovation has taken place. Why these two 
points matter? Firstly, public affairs are very broad issues that materialize in almost every aspect of human beings. Knowing which aspects of life and what kind of government intervention implemented to solve the problems will be an advantage to identify the gap of policy sector or policy area. Policymakers can identify whose lack of innovation or even heaps of innovation in delivering public services. Secondly, as an archipelago consisting of more than 17,000 islands and 497 local governments, Indonesia is regarded as a complexmulti-level government system. Mapping innovation distribution among regions in the geographical perspectives may help the Indonesian government to know the disparity among regions. Referred to the archipelago perspective, the geographical analysis is designated to Java and non-Java.

\section{The backbone of analysis: configuring the landscape}

The framework of analysis was built by adopting major dimensions of public sector innovation include: innovators, innovation types, innovation goals and outcomes, policy sector in which innovation implemented and geographical perspective Figure 1.

To ease the analysis, this paper conceptualizes the operational definition as follows Table I.

\section{Data, method and procedure}

This study implemented archival research as a research strategy. To investigate the characteristic of innovations implemented in Indonesia's public sector and portray its landscape, the data were drawn from three official books, which report the top 99 of Indonesia's public service innovation award in three consecutive years since 2014 to 2016 (KemenpanRB, 2014, 2015, 2016 ). These books were published by the Ministry of Administrative Reform of the Republic of Indonesia to record the nominees of the Indonesian public service innovation competition held annually and organized by the Ministry. Thus, there were 297 reports compilation in these books as the core sources of

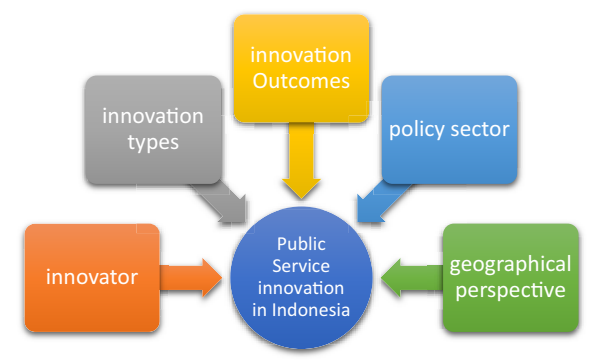

Figure 1.

Backbones of analysis
Public service innovation in Indonesia

\begin{tabular}{|c|c|}
\hline Concept & Operational definition \\
\hline Innovator & Organization, which implement public service innovation \\
\hline Innovation type & The type of innovation, which has been implemented in a certain public organization \\
\hline Innovation outcomes & The impact of innovation initiatives in public service deliveries \\
\hline Policy sector & In which policy area the innovation initiative has been implemented \\
\hline $\begin{array}{l}\text { Geographical } \\
\text { perspective }\end{array}$ & The geographic area in which public service innovation took place \\
\hline
\end{tabular}


INMR

17,1

analysis. These reports represent nominees' innovative projects and their practicalities of public service innovation, as well as the outcomes.

The 297 reports compilation were analyzed based on the framework of analysis including innovators, innovation types, innovation impacts, policy sector and geographical perspective using content analysis as a method. To ease the administration of archival data and analysis, the author used NVivo 11, data analysis software for qualitative data, as a data management tool. The procedure of data analysis can be reported as follows. Firstly, the data in portable document format were imported to the software as a source of analysis. Secondly, the author designed the framework of analysis using nodes as themes of the study. In other word, the framework analysis, which includes innovators, innovation types, innovation outcomes, policy sectors, and geographical perspective were treated as nodes where the sources will be coded. Thirdly, the source was coded based on the designed-nodes in the system. There are two basic analysis of data comprises of the aggregate characteristic of public sector innovation covering 2014, 2015 and 2016 competition year and trend analysis, which investigated the dynamic and change of innovation landscape across periods. Finally, the author conducted a data visualization process to present the landscape of public sector innovation in an attractive manner.

\section{Result: what kinds of innovation were they?}

The landscape is built from the framework of literature that has been developed including innovators, innovation types, innovation goals, innovation impacts, policy areas and geographical perspective across three years competition. Therefore, the presentation of the result will be focused on each competition year followed by trend analysis.

\section{4 competition year}

The investigation through tree map analysis, which identifies nodes compared by the number of coding references shows that local government was a dominant actor in innovation by contributing 75 innovation initiatives in the public service deliveries. It was followed by 21 central government agencies that successfully carried public service innovation in the second place. Only three independent agencies qualified as innovators in 2014 competition year, which was the smallest number nominees to be awarded as innovators. In 2014, the nominees were dominated by innovation held in the local government with 75.8 per cent.

In regards of innovation types, nominees were likely implementing process and governance-typed of innovation by 52 and 25 per cent, respectively. Product and service innovation emerged in 14 agencies, while the conceptual-type of innovation was relatively rare indicated by small proportion less than 10 per cent from the whole nominees. In 2014 competition year, the outcomes from public service innovation mostly attain efficiency in the business processes; improve citizen satisfaction; and tackling societal problems. The top three outcomes cumulate 63 per cent of the whole identified outcomes, where the rest consists of effectiveness, transparency and corruption reduction and involving citizen participation. Only one innovation fosters the involvement of private sector contributing in public services. This indicates lack of collaboration across governance actors in public service innovation. Let now move to the policy sector in which innovation evolved. The top three innovations in public service delivery are health, education and the improvement of state apparatus and bureaucracy. However, innovation on security sector is rarely found among nominees. The last analysis, goes to the geographical aspect, which shows that the innovation winners come from Java Island (63 per cent) and the rest of innovation (37 per cent) were implemented in non-Java Island Figure 2. 


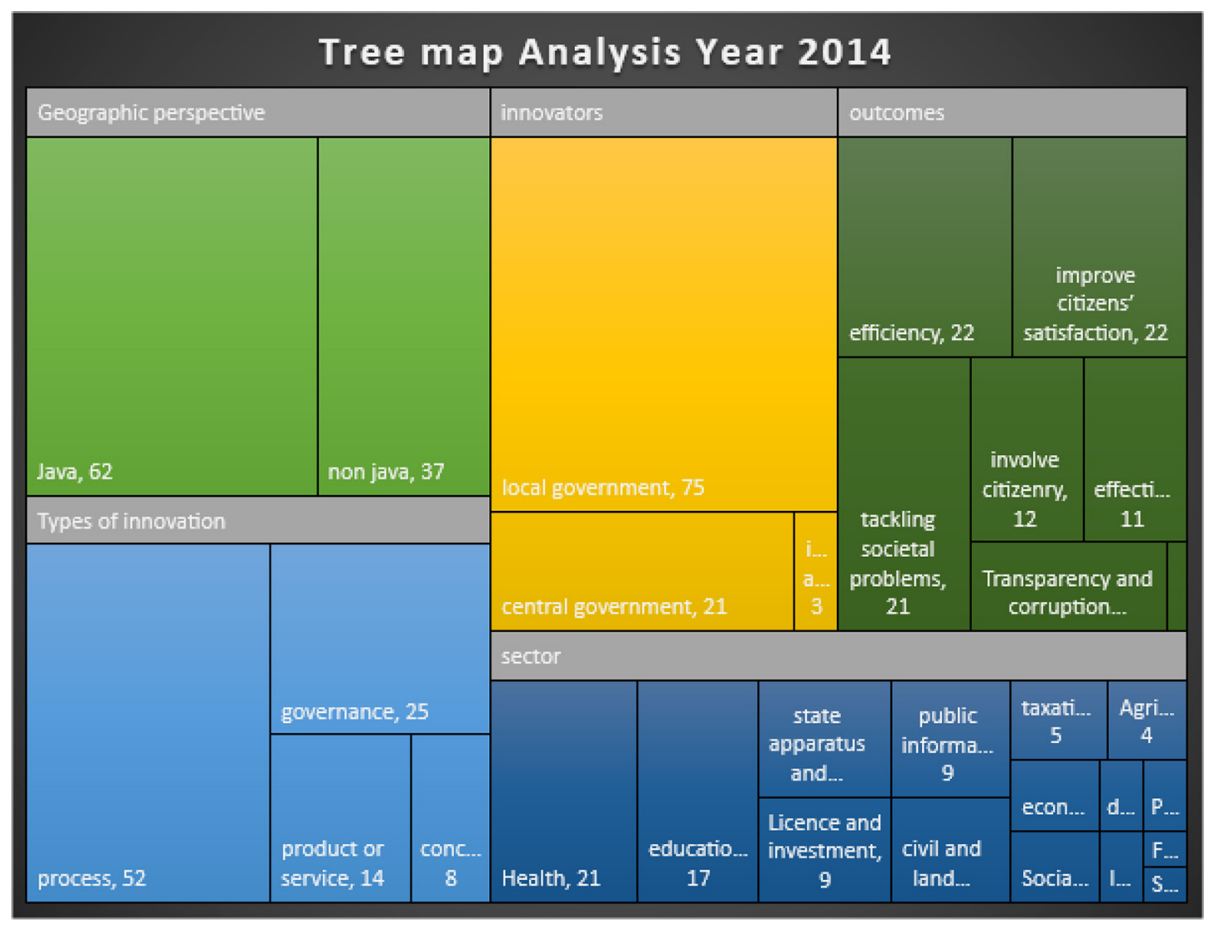

Public service innovation in Indonesia

33

Figure 2.

2014 nominees tree map analysis

\section{5 competition year}

In the 2015 competition year, only two categories of actor have been identified as innovators. They are 79 local governments and 20 central governments admitted as nominees. Unlike a year before, not a single independent public-agency entered into the list as a nominee. From the aspect of innovation types, the characteristic was likely similar to 2014 competition year. The process innovation and governance-type of innovation were still prevalent by 53 and 22 innovation programs, respectively. Again, conceptual-typed of innovation emerged as the smallest portion albeit it has improved from 8 to 11 initiatives in 2015. The outcome from innovation initiatives linked with efficiency themes and tackling societal problems were highly found. The outcome for improving citizen's satisfaction went down from 22 to 8 initiatives, whilst, encouraging citizen participation had increased from 12 to 18 initiatives. From the policy sector perspective, it was not relatively different from 2014 competition year. The health (27 initiatives) and education sector (13 initiatives) were still evidence followed by economic development and civil administration as the area and sector of innovation. Geographically, nominees in 2015 came from three categories. The Java-based public service innovation remained at the top by 62 nominees, while non-Java based initiatives were represented by 36 innovators. One innovation was conducted in the foreign territories especially managed by Ministry of Foreign Affairs, which implemented in Johor Bahru, Malaysia to provide education services for children of Indonesian citizens working in Malaysia Figure 3. 


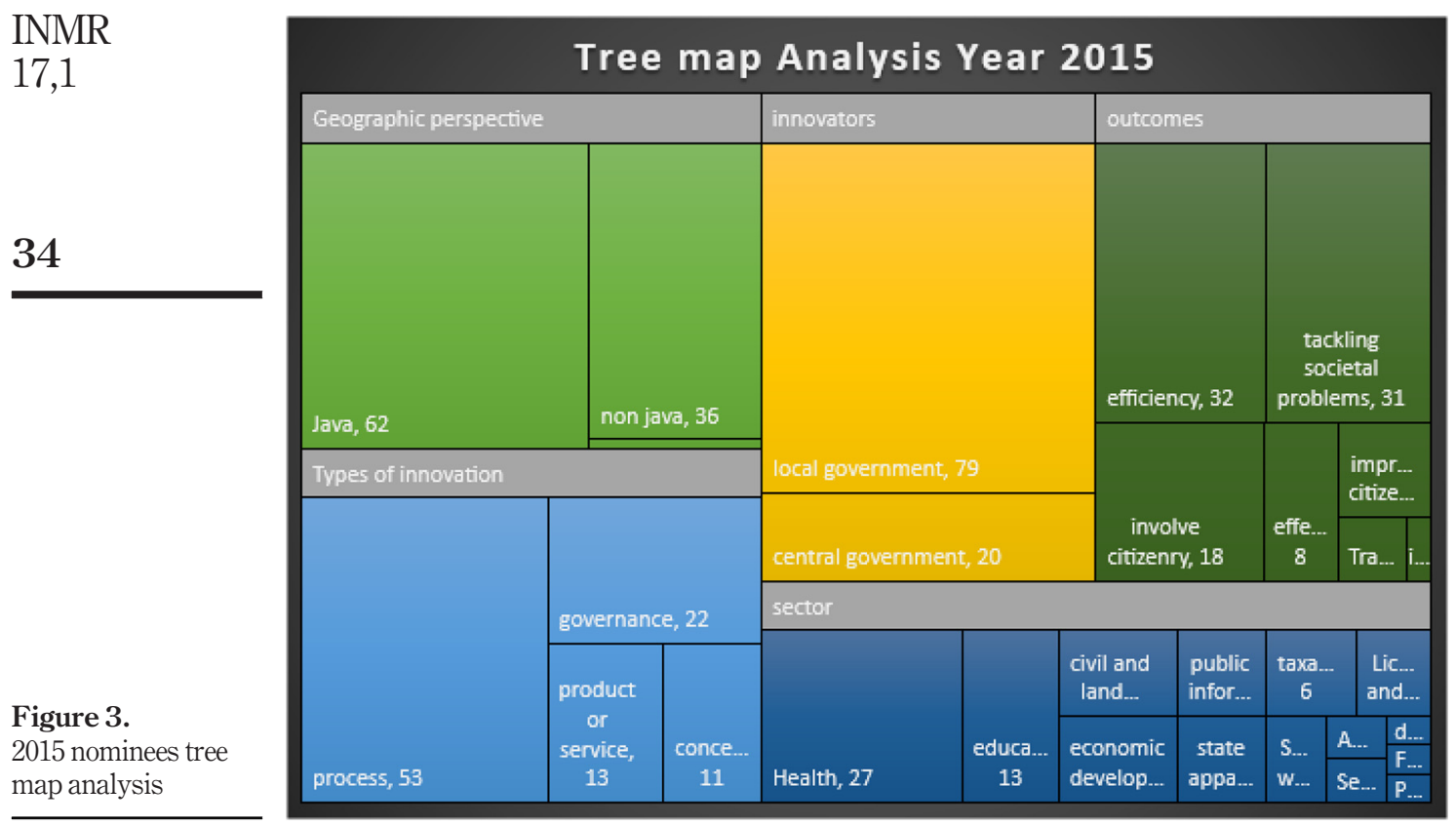

\section{6 competition year}

The category of innovators in 2016 consists of three main actors. They are 80 local government organizations, 14 organizations from central government agencies and 5 stateowned enterprises. The states owned enterprises started to involve in the public service innovation in the 2016 competition year and were represented by five innovation programs. The process innovation still dominates the list on innovation types followed by product or service innovation and governance innovation. In regard to the outcome of innovation, the 2016 competition year was dominated by tackling societal problems followed by effectiveness and service process efficiency. Unlike 2015, the innovation, which is aimed to push citizen participation has dropped from 18 to only 3 initiatives. The analysis on the policy sector shows that health sector was still the preferred area on doing innovation initiatives increased from 27 to 34 initiatives. Other sectors were education, public information, energy, environment, social work and pro-poor policy, state apparatus and bureaucracy, shipping and trading, taxation, public procurement, and economic development. The innovation programs were mostly held in Java (70 initiatives) and island outside Java (29 initiatives) Figure 4.

\section{Characteristic and trend analysis 2014-2016}

Given the data set of public service innovation nominees in three consecutive years, it allows author to conduct accumulative landscape and trend analysis to explicate the clearer picture of innovation in Indonesian public sector. The innovator from the public service innovation competition 2014-2016 was dominated by local government (78.8 per cent) followed by central government (18.5 per cent), while independent-government agencies and stateowned enterprises share the same portion ( 2.7 per cent). The trend analysis also shows that local government as innovator was steadily increased from 75 in 2014, 79 in 2015 and 80 in 


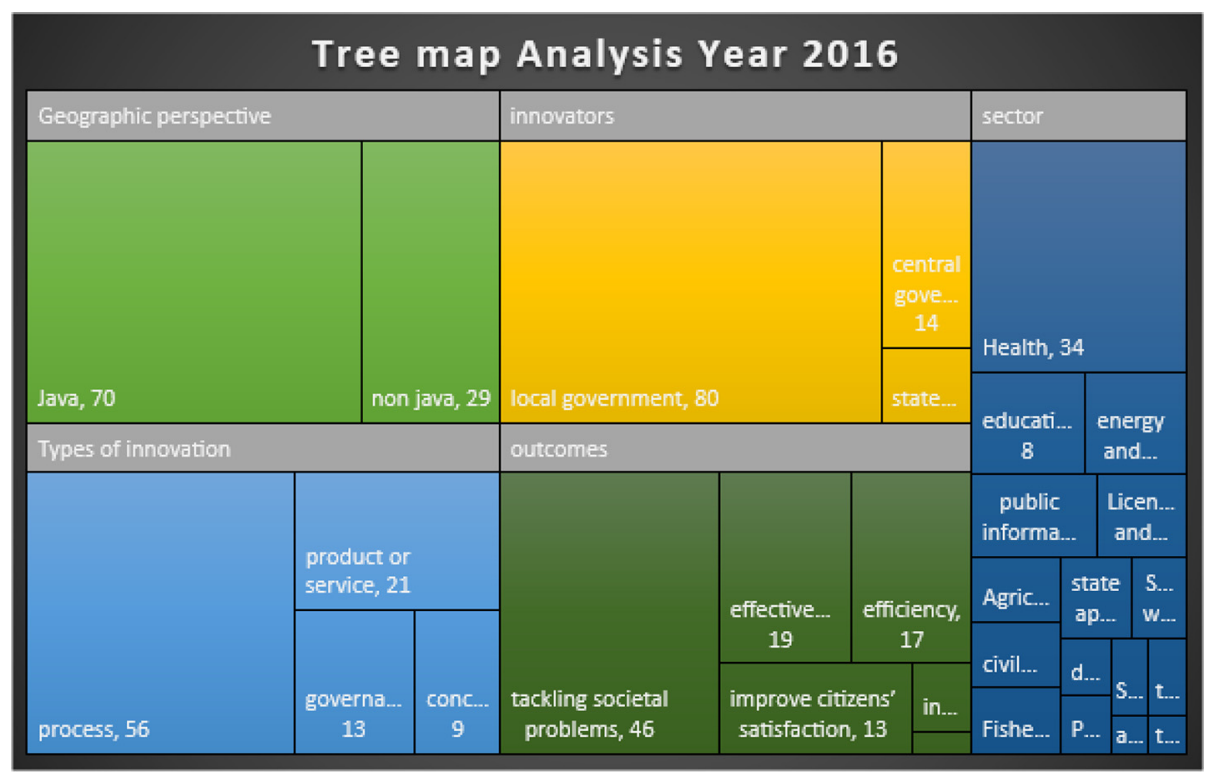

Public service innovation in Indonesia

2016. For the central government, (unlike local government) the nominees reduced in numbers from 21 in 2014 to 14 in 2016. The independence agency was among the nominees in 2014 only but no occurrence in both 2015 and 2016. While the state-owned enterprises were the newcomers as innovators in 2016 competition year.

In regards the innovation types, the process innovation had been widely implemented, which shows 54.2 per cent or 161 occurrences from 297 innovation initiatives from 2014 to 2016. The trend of process innovation has increased from 52 in 2014 to 53 in 2015 to 56 in 2016 competition year. While conceptual innovation was the least implemented by public organization ( 28 records from total 297 initiatives). The other types of innovation have dynamically changed in pattern across the years. For instance, product or service innovation started from 14 in 2014 and then went down by 8 in 2015 before raised to 19 in 2016. This pattern also happened to conceptual innovation started from 8 in 2014 then increased to 11 in 2015 before decreased to 9 in 2016. The governance innovation was the only innovation type that is declined in numbers indicated by the number depreciation from 25 in 2014 to 13 in 2016.

The outcomes from the competition were varied. The top two outcomes were tackling societal problems (33 per cent) and improve efficiency in public service deliveries (23.9 per cent). The nominees highly leaned to the goals of tackling societal problems across three years competition. This outcome had significantly risen from 21 in 2014 to 31 in 2015 to 46 in 2016. The impact on the efficiency ranked in second place started from 22 in 2014 and reached its peak in 2015 by 32 before went down to 17 in 2016. One of the salient finding is that the lack of outcome in which urge the involvement private partner to contributing in public services. The analysis shows only two initiatives yielded to this outcome, which were happened in 2014 and 2015, yet no impact on private sector involvement found in 2016 competition year.

From the policy sector perspective, public service innovation can be found in various public issues. The analysis has identified that the innovation can be found in 
INMR

17,1

agriculture, aviation, civil and land administration, development planning, economic development, education, energy and environment, fisheries, health, licenses and investment, procurement, public information, security, social work and pro-poor policy, state apparatus and bureaucracy, taxation, infrastructure and trade affairs. From 2014 to 2016, the health and education sector were the most prominent innovation among nominees. The health sector encountered a significant number from 21 in 2014 climbed up to 27 in 2015 and then reached by 34 in 2016. Unlike health sector, innovation in education had diminished from 17 in 2014 to 13 in 2015 and ended by 8 in 2016. The relatively new sectors appeared in 2016 such as energy, shipping and trading were contributed by state-owned enterprises. From the geographical aspect, 194 innovations took place in Java, 102 innovations were held in the island other than Java, and only 1 innovation conducted in the foreign territory.

\section{Discussion}

The result of this study shows that local government is likely the most prominent performer of innovation in Indonesian public-sector. This finding supports the systematic review of literature on public sector innovation from 1990-2014 conducted by De Vries et al. (2016). Their systematic literature review recorded 27 per cent of published articles emphasized on local government setting, which was the biggest portion of publications on public sector innovation. As an institution dealing with endusers of public service provisions, it makes sense that local government institutions need to be more innovative facing the complexities dealing with their citizens. The local level governing body is the forefront of public service in which acting as a spearhead of government policies and providing public services. Another explanation may come from the perspective of the regulatory framework. The Government of Indonesia issued Regulation Number 38 Year 2017 about local innovation. The regulation aims to improve service performance in the local government level. The initiative was directed to achieve public service quality improvement, citizen empowerment and local competitiveness. Given this support, the local governments may get funding, as well as budget allocation to accommodate public service innovation initiatives.

A study by Bartlett and Dibben (2002) suggested two typologies of public sector innovation and entrepreneurship, which are focus on external public needs and internal managerial empowerment, respectively. Their study was drawn from 12 case studies of innovation in the local government. It likely explains the motives of local governments who engage in the innovation project have successfully integrated external public needs and internal managerial empowerment. The finding of this present study supports their conclusion where the outcome of innovation is profoundly found to tackle the societal problem as external public needs and business process efficiency as internal managerial empowerment.

Another key finding is that there is a lack of collaboration between public organizations, private actors, and not for profit organizations to cooperate in executing innovation in public services. While, many literatures suggest that collaboration and co-production in public services are associated with successful innovation initiatives (Agolla \& Lill, 2013; Borins, 2001; Hartley, 2005; Hartley \& Downe, 2007; Osborne, Radnor \& Nasi, 2013), there is a gap in the practical domain of Indonesia's context. The portrait of innovation types and innovators and their trend in three consecutive years had demonstrated this gap. This study has shown that governance-typed of innovation was relatively less in number compared to process innovation. Also, there is no evidence that innovation in public services has been conducted 
by collaboration among governance actors. Another argument can be positioned in the outcome-based innovation in which the involvement of private partner in public service deliveries is rarely happened. Only one outcome in 2014 and 2015 identifies that innovation implemented by nominees has attained the involvement of private partner to contributing in public services.

To address this issue, there is a need of encouragement to build collaboration among actors in public service innovation initiatives. Referring to what Osborne, Radnor and Strokosch (2016) suggest on service-dominant approach where the citizen as a customer is placed in the crux of service delivery, collaboration, co-creation and co-production is needed to be applied in the future public service policies and strategies.

\section{Conclusion and future research}

Calling back to the motivation of this study, which is aimed to capture the landscape of public service innovation in Indonesia, some key important findings can be summarized. Overall, the public service innovation nominees from the national public service innovation competition in Indonesia from 2014-2016 were dominated by local governments. In terms of innovation type, the process innovation, which is the amalgamation of technological and administrative dimensions of innovation was a fad in the Indonesian public service innovation. From the outcome-based analysis, the mostly occurrence outcomes of public service innovation are tackling societal problems in health and education policy sector.

Some important points of public service innovation dynamic and change in Indonesia and its policy implications can be summarized as follows. Firstly, public service innovation implementation in Java was greater than non-Java Islands. This indicates the discrepancy of governance capacity between Java and non-Java Island. This fact may inform policymakers to consider the improvement of governance capacity for public bureaucracy in non-Java Island. The call for equal capacity building between Java and non-Java bureaucracy may tackle this issue.

Secondly, process innovation dominated the Indonesian public service innovation, which was growing steadily in numbers while governance-typed innovations were rarely found. Unlike process innovation, which emphasizes on internal business process to deliver services, the governance innovation requires collaboration and interaction with other parties. As suggested by literature that collaboration matters in the public sector innovation, the Government of Indonesia may consider bringing strategies, as well as policy direction that endorses and facilitate the collaboration among stakeholders in the public sector innovation initiatives.

Future research can be streamed into three trajectories. Firstly, further study with the extension of samples (not only sourced from the nominees but also all submitted initiatives) needs to be conducted to obtain a thorough analysis and representation of public service innovation in Indonesia. Secondly, albeit there are some international instruments in measuring innovation in the public sector, it is beneficial to design the measurement tools on national public service innovation, as there is no availability of measurement to assess Indonesian public service innovation index. Thirdly, the inquiry whether competition or award scheme as an effective policy instrument needs to be investigated. Given this condition, doing a policy evaluation study on public service competition will prove whether public service competition spurs innovation in the public sector or it has no effect on accelerating public sector innovation.

Public service innovation in Indonesia

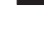


INMR

17,1

\section{8}

\section{References}

Abernathy, W., Clark, K., \& Kantrow, A. (1983). Industrial renaissance: Producing a competitive future in America, New York, NY: Basic Books.

Agolla, J. E., \& Lill, J. B. V. (2013). Public sector innovation drivers: a process model. Journal of Social Sciences, 34, 165-176. http://dx.doi.org/10.1080/09718923.2013.11893128

Anggadwita, G., \& Dhewanto, W. (2013). Service-innovation-in-public-sector: A case study on PT. Kereta api Indonesia. Journal of Social and Development Sciences, 4, 308-315. http://dx.doi.org/10.13140/ 2.1.1736.8002

Ansell, C., Torfing, J., \& Keast, R. (2017). Network governance. Handbook on theories of governance, Cheltenham, UK: Edward Elgar Publishing. http://dx.doi.org/10.4337/ 9781782548508.00048

Bartlett, D., \& Dibben, P. (2002). Public sector innovation and entrepreneurship: Case studies from local government. Local Government Studies, 28, 107-121. http://dx.doi.org/10.1080/714004159

Bhatti, Y., Olsen, A. L., \& Pedersen, L. H. (2011). Administrative professionals and the diffusion of innovations: the case of citizen service centres. Public Administration, 89, 577-594. http://dx.doi. org/10.1111/j.1467-9299.2010.01882.x

Bloch, C., \& Bugge, M. M. (2013). Public sector innovation-from theory to measurement. Structural Change and Economic Dynamics, 27, 133-145. http://dx.doi.org/10.1016/j.strueco.2013.06.008

Bommert, B. (2010). Collaborative innovation in the public sector. International Public Management Review, 11, 15-33. http://dx.doi.org/10.1017/CBO9781316105337.006

Borins, S. (1998). Innovating with integrity: How local heroes are transforming American government, Washington, DC: Georgetown University Press.

Borins, S. F. (2001). Encouraging innovation in the public sector. Journal of Intellectual Capital, 2, 310-319. http://dx.doi.org/10.1108/14691930110400128

Borins, S. (2008). Innovations in government, Washington, DC: Brookings Institution Press.

Caiden, G. (1969). Administrative reform, Chicago: Aldine Publ.

Damanpour, F., \& Schneider, M. (2009). Characteristics of innovation and innovation adoption in public organizations: Assessing the role of managers. Journal of Public Administration Research and Theory, 19, 495-522. http://dx.doi.org/10.1093/jopart/mun021

Diamant, A. (1967). Innovation in bureaucratic institutions. Public Administration Review, 27, 77-87. http://dx.doi.org/10.2307/973189

Dolowitz, D., \& Marsh, D. (1996). Who learns what from whom: a review of the policy transfer literature. Political Studies British Studies, 21, 343-351. http://dx.doi.org/10.1111/j.14679248.1996.tb00334.x

Dolowitz, D., \& Marsh, D. (2000). Learning from abroad: the role of policy transfer in contemporary policy-making. Governance, 13, 5. http://dx.doi.org/10.1111/0952-1895.00121

Evans, M., \& Davies, J. (1999). Understanding policy transfer: a multi-disciplinary perspective. Public Administration, 77,361-385. http://dx.doi.org/10.1111/1467-9299.00158

Fahlevi, H. (2014). The Innovation of the role of accounting in public hospitals - lesson learned from hospital financing reform in Indonesia and Germany, Dissertation, Retrieved from https://dopus. uni-speyer.de/frontdoor/deliver/index/docId/928/file/HeruFahlevi.pdf

Fragerberg, J., Mowery, D., \& Nelson, R. (2005). The oxford handbook of innovation, Oxford, UK: Oxford University Press.

Hansen, S., \& Wakonen, J. (1997). Innovation, a winning solution? International Journal of Technology Management, 13, 345-358. http://dx.doi.org/10.1504/IJTM.1997.001668

Hartley, J. (2005). Innovation in governance and public services: past and present. Public Money and Management, 25, 27-34. http://dx.doi.org/10.1111/j.1467-9302.2005.00447.x 
Hartley, J., \& Downe, J. (2007). The shining lights? Public service awards as an approach to service improvement. Public Administration, 85, 329-353. http://dx.doi.org/10.1111/j.1467-9299.2007.00652.x

Jati, W. R. (2011). Inovasi pelayanan publik setengah hati: Studi pelayanan publik SAMSAT kota Yogyakarta.Jurnal Ilmu Sosial Dan Ilmu Politik, 15, 68-78.

KemenpanRB. (2014). Top 99 inovasi pelayanan publik Indonesia 2014, Jakarta, Indonesia: KemenpanRB.

KemenpanRB. (2015). Top 99 inovasi pelayanan publik Indonesia 2015, Jakarta, Indonesia: KemenpanRB.

KemenpanRB. (2016). Top 99 inovasi pelayanan publik Indonesia 2016, Jakarta, Indonesia: KemenpanRB.

KemenpanRB. (2017). Laporan kinerja kementerian pendayagunaan aparatur negara dan reformasi birokrasi tahun 2016, Jakarta, Indonesia: KemenpanRB.

Klijn, E., \& Koppenjan, J. (2012). Governance network theory: Past, present and future. Policy and Politics, 40, 187-206.

Kusumasari, B., Setianto, W. A., \& Pang, L. L. (2018). A study on digital democracy practice: Opportunities and challenges of e-Health implementation in Indonesia. Jurnal Ilmu Sosial Dan Ilmu Politik, 22, 1. http://dx.doi.org/10.22146/jsp.28863

Lembaga Administrasi Negara. (2014). Handbook inovasi administrasi negara, Cetakan I, Jakarta, Indonesia: Pusat INTAN-DIAN-LAN.

Mccann, E., \& Ward, K. (2013). A multi-disciplinary approach to policy transfer research: Geographies, assemblages, mobilities and mutations. Policy Studies, 34, 2-18. http:/dx.doi.org/10.1080/ 01442872.2012 .748563

Moore, M., \& Hartley, J. (2008). Innovations in governance. Public Management Review, 10, 3-20. http:// dx.doi.org/10.1080/14719030701763161

Mulgan, G., \& Albury, D. (2003). Innovation in the public sector, London, UK: Cabinet Office Strategy Unit.

Osborne, S. P. (1998). Naming the beast: Defining and classifying service innovations in social policy. Human Relations, 51, 1133-1154. http://dx.doi.org/10.1177/001872679805100902

Osborne, S. P., Radnor, Z., \& Nasi, G. (2013). A new theory for public service management? To3ward a (public) service-dominant approach. The American Review of Public Administration, 43, 135-158. http://dx.doi.org/10.1177/0275074012466935

Osborne, S. P., Radnor, Z., \& Strokosch, K. (2016). Co-Production and the Co-Creation of value in public services: a suitable case for treatment? Public Management Review, 18, 639-653. http://dx.doi. org/10.1080/14719037.2015.1111927

Rogers, E. (2003). Diffusion of innovations (5th ed.). New York, NY: Free Press.

Rogers, E. M., Medina, U. E., Rivera, M. A., \& Wiley, C. J. (2005). Complex adaptive systems and the diffusion of innovations. The Innovation Journal: The Public Sector Innovation Journal, 10, 1-26. Retrieved from http:/citeseerx.ist.psu.edu/viewdoc/download?doi=10.1.1.130.8047\&rep=rep1\& type $=$ pdf

Santoso, M. I. (2015). Applying interactive planning on public service leadership in the directorate general of immigration Indonesia. Procedia - Social and Behavioral Sciences, 169, 400-410. http://dx.doi.org/10.1016/j.sbspro.2015.01.326

Sørensen, E., \& Torfing, J. (2012). Introduction collaborative innovation in the public sector. Innovation Journal, 17, 1-14. Retrieved from https://search.proquest.com/openview/ 0f40c00fe7d85f36ed04c94d202aed99/1?pq-origsite=gscholar\&cbl=2028854

Stone, D. (2001). Learning Lessons, Policy Transfer and International Diffusion of Policy Ideas. CSGR Working Paper No.69/01 April 2001. Centre for the Study of Globalisation and Regionalisation. Coventry, UK: University of Warwick.

Sutanto, E. M. (2017). The influence of organizational learning capability and organizational creativity on organizational innovation of universities in East java, Indonesia. Asia Pacific Management Review, 22, 128-135. http://dx.doi.org/10.1016/j.apmrv.2016.11.002

Public service innovation in Indonesia

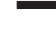


INMR

17,1

Sweezy, P. (1943). Professor Schumpeter's theory of innovation. The Review of Economics and Statistics, 25, 93-96.

Ulibarri, N., \& Scott, T. A. (2017). Linking network structure to collaborative governance. Journal of Public Administration Research and Theory, 27, 163-181. http://dx.doi.org/10.1093/jopart/muw041

Urbancova, H. (2013). Competitive advantage achievement through innovation and knowledge. Journal of Competitiveness, 5, 82-96. http://dx.doi.org/10.7441/joc.2013.01.06

De Vries, H., Bekkers, V., \& Tummers, L. (2016). Innovation in the public sector: A systematic review and future research agenda. Public Administration, 94, 146-166. http://dx.doi.org/10.1111/ padm.12209

Walker, R. M. (2013). Innovation special issue: Internal and external antecedents of process innovation in local government: A review and extension. Public Management Review, 16, 1-24. http://dx. doi.org/10.1080/14719037.2013.771698

Walker, R. M., Jeanes, E., \& Rowlands, R. (2002). Measuring innovation - applying the literature-based innovation output indicator to public services. Public Administration, 80, 201-214. http://dx.doi. org/10.1111/1467-9299.00300

Ziemnowicz, C. (2013). Joseph A. Schumpeter and innovation. In E. G. Carayannis, (Ed.), Encyclopedia of creativity, invention, innovation and entrepreneurship, (pp. 1171-1176). New York, NY: Springer. http://dx.doi.org/10.1007/978-1-4614-3858-8_476

\section{Corresponding author}

Arif Budy Pratama can be contacted at: arifpratama@untidar.ac.id

Associate Editor: Felipe Mendes Borini

For instructions on how to order reprints of this article, please visit our website: www.emeraldgrouppublishing.com/licensing/reprints.htm

Or contact us for further details: permissions@emeraldinsight.com 